Original Research Paper

\title{
Analysis of the Age Replacement Method to Reduce Tool Downtime
}

\author{
Irwan Sukendar ${ }^{1}$, Akhmad Syakhroni ${ }^{1}$, Muhammad Reza Prawira ${ }^{1}$ \\ ${ }^{1}$ Industrial Engineering Department, Industrial Engineering Faculty, Universitas Islam \\ Sultan Agung. Semarang, Indonesia.
}

Article History

Received:

16.02.2020

Revised:

20.03.2020

Accepted:

24.04.2020

*Corresponding Author:

Irwan Sukendar

Email:

irwan@unissula.ac.id
Abstract: A manufacturing company engaged in the manufacturing of diesel engines in Indonesia has a problem with high downtime. The most frequent replacement frequency is in the cylinder liner line which in April - June 2018 has 1254 units of replacements, besides that the cylinder liner line also has the highest downtime of 7243.94 minutes. To overcome this problem, it is necessary to schedule tool replacement using the Age Replacement method, where this method is to determine the tool replacement schedule with the least downtime. After that the calculation is done using the Availability method, where the higher the Availability value of a tool, the better the condition of the tool to operate according to its function. And finally the calculation is done using the Reliability method, where the higher the value of the reliability of a tool, the less likely the damage will occur to the tool.

Keywords: Tool, Downtime, Age Replacement, Availability, Reliability. 


\section{Introduction}

A manufacturing company producing various diesel engines. The diesel engine produced is a Horizontal Diesel Engine with an engine capacity of 5-31.5 HP (RD / RK / ER / KND series). This Diesel engine can be used for tractors, welding machines, power plants, water pumps, construction machinery, compressors, and boat propulators, rice grinders (rice thresher, grain breaking machines, and scourers) and for other businesses.

The production process begins with the Finish Part and Blank Part both from sub-contractors (Indonesia \& Thailand) and those from Japan entering the Ware House by taking samples for inspection at the inspection. Parts that have been inspected for some of the samples are directly entered into the assembling department (assembly) and some are entered into the machining department first. In this machining section, the parts are processed again according to the needs in the assembling section.

Before entering the assembling department, several samples are taken for re-inspection. In addition to assembling and machining, there are also blank parts and finish parts that go into the washing and pakarizing sections to be washed first. From washing and pakarizing then the part is painted in the painting part. The assembling department is divided into four lines, namely the main assembling line, the test running line, the washing \& painting line and the final assembling line. Each line is equipped with a display to control the number of products produced. On the display is written plans and actual diesel engines produced. After finishing the packing process the machine is brought to the Ware House Finish Good section and then marketed until it reaches the hands of consumers.

The machining department has 8 lines that will process blank parts from sub contractors which will later be finished parts and will be assembled in the assembling department. These lines are cylinder head line, gear case line, flywheel line, cylinder liner line, bracket rocker arm line, OLD crankcase line, NEW crankcase line, crank shaft line. All lines in the machining department have tool components. Continuous use of the machine causes the tool to wear out quickly and must be replaced. Tool replacement is not currently carried out using scheduling so that when a tool has been damaged or is out of use then the tool will be replaced immediately. Tool replacement in this way is disruptive in production because it takes time to disassemble the engine and replace components with new ones. Whether or not a tool is replaced depends on the complexity of the machine. The more complex the machine, the longer the tool change so that resulting in high downtime. The most frequent replacement frequency is in the cylinder liner line which in April - June 2018 has 1254 units of replacements, besides that the cylinder liner line also has the highest downtime of 7243.94 minutes.

Research on determining the interval of replacement of engine components has been carried out by previous researchers. The study used is to use the Age Replacement method, in this method of replacement prevention is done by re-setting the time interval of the next material prevention in accordance with a predetermined time interval if there is damage that requires action to be replaced. The purpose of the research carried out by several researchers is divided into two objectives, the first objective is the determination of component replacement intervals by reducing downtime while the second goal is the determination of component replacement intervals with minimal cost.

Research on component replacement intervals with downtime minimization is carried out by [1] on turbine engines in PT PLN (Persero) Ombilin Generating Sector. This research discusses the right strategy to keep turbine engines operating by determining optimal maintenance time intervals to reduce downwtime. The method used in determining the maintenance intervals on turbine engine components is to use the age replacement, availability and reliability methods. The purpose of this study is to determine the maintenance time intervals of components on turbine engines with the criteria for minimizing downtime. Then in further research conducted by [2]. This study discusses the preventive maintenance planning of cane cutter components in PG Kebon Agung Malang. Damage to the blade components in the cane cutter I machine has the highest level of severity. The method used is the age repalacement because component replacement is done when the component reaches maximum age. In addition, the availability and reliability methods are used.

Other studies conducted by [3]. This study discusses the maintenance period and examination of the heading machine punch tool that often suffer damage, the method used is Age Replacement. By doing preventive maintenance, there has been a reduction in downtime, increased availability, and reliability of production machines. Then [4] conduct research on the optimal maintenance of blade components and as cake breaker conveyor which is often damaged, damaged cake cake conveyor can cause the production process to stop due to the as cake breaker conveyor and the production facility runs sequentially. The method used in this study is age replacement. The purpose of this study is to determine the optimal maintenance schedule by reducing downtime. Then further research was 
conducted by [5]. This study discusses the maintenance of mold gear engine components that are damaged. The proposal for preventative maintenance is focused on the critical components of mold gear. The method used is Age Replacement with the criteria for minimizing downtime. Then [6] conduct research on preventive maintenance of dumping grate components on boiler engines that experience at PG Rejo Agung Baru Madiun. In the production process at PG Rejo Agung Baru Madiun, there was a problem, namely stopping production activities due to damage from the engine. The method used is the optimal preventive replacement age model.

In addition there is research on component replacement intervals based on cost minimization criteria conducted by [7]. This study discusses engine maintenance on the PO bus fleet. Harapan Jaya Tulungagung. This research was conducted on the Hino brand engine that has the highest level of damage. The purpose of this study is to determine the optimal costs for maintaining the Hino brand bus fleet. Other studies conducted by [8]. This study discusses the preventative maintenance of components at PT CC KAI DE CC 201 Series 99 locomotive. The method used in this research is Age Replacement

In other studies there is also a combination of two objectives, namely reducing downtime and costs, as in research conducted by [9]. This study discusses the scheduling of B.Flute machine maintenance at PT. AMW PT AMW has many machines used in the production process so that the maintenance process must be managed properly and not hamper or disrupt existing production process schedules. As well as research conducted by [10]. This study discusses the determination of the age of replacement of U41 printing system components. The component is often damaged, causing losses for the company. The method used to solve the problem is Age Replacement. The purpose of this study is to determine the age of replacement of the U41 unit printing system components that provide the lowest cost expectations and reduce downtime

Based on literature studies from several journals, the right step to determine the scheduling or replacement of tool intervals on cylinder liner lines in machining department based on reduced downtime is to use the Age Replacement method, Availability method, and Reliability method. The Age Replacement method is used to determine the schedule or determination of component replacement intervals by reducing downtime. Availability method to find out the level of availability or readiness of the machine to operate again when the machine has been repaired. While the Reliability method (reliability) to show how the size of a component to operate properly.

The stages of this research began by determining the critical components using the Pareto Diagram. Calculates the value of TTR (Time to Repaire) and TTF (Time to Failure) of critical components. After that, determine the distribution used on the TTR (Time to Repaire) and TTF (Time to Failure), the test is carried out with a goodness of fit test. Calculate the value of MTTF (Mean Time to Failure) and MTTR (Mean Time to Repaire). After that, do the calculation of the damage prevention replacement time interval to reduce total dowmtime. Then do the component replacement schedule calculation, perform downtime calculations before and after calculations using Age Replacement. Besides that, the availability and availability methods are used. The availability method is to determine the level of availability or readiness of the machine to operate again when the machine has been repaired. While the reliability method (reliability) to show how the size of a component to operate properly.

\section{Theoritical Base}

\subsection{Tool Definition}

Tool is a tool used to separate / cut some material (metal) from its parent object with permanent cutting. Separation of part of the material is done to get a component that has a shape and size that has been determined in accordance with the working drawings. In the process of making a component on a production machine tool, the tool is a tool that functions very important [11].

\subsection{Downtime Definition}

Downtime can occur because the system fails to function due to unplanned events, for example such as when a unit is damaged that can interfere with overall performance so it requires a certain amount of time to restore the function of the unit to its original condition [12] .

\subsection{Time to Failure}

The damage time used is TTF (Time to Failure) and TTR (Time to Repaire). TTF is the time difference when the first damage is repaired until the next damage. TTF can also be called the 
time interval between damage. While TTR is the time difference used to make repairs until the machine can operate again or is called downtime [2] .

\subsection{Age Replacement Dengan Kriteria Minimasi Downtime}

Age replacement is preventive replacement performed depending on the service life of the component. The following is an age replacement formulation with downtime minimization criteria:

$\mathrm{D}(\mathrm{tp})=\frac{\text { Tulal expectation duwnline per cycle }}{\text { Expectation cycle time }}$

The formula for total downtime expectations per cycle and expected cycle lengths is described as follows:

- Total downtime expectations per cycle:

$=$ Downtime due to preventive cycles $\mathrm{x}$ probability of preventive cycles + downtime due to damage cycles $\mathrm{x}$ downtime due to damage cycles

$=\operatorname{TpR}(\mathrm{p})+\mathrm{Tf}[1 \mathrm{R}(\mathrm{tp})]$

- Long cycle time expectations:

$=$ Preventive cycle length $\mathrm{x}$ probability of preventive cycle + expectation of damage cycle length $x$ probability of damage cycle. $=(\mathrm{tp}-\mathrm{Tp}) \mathrm{R}(\mathrm{tp})+[\mathrm{M}(\mathrm{tp})+\mathrm{Tf}][1-\mathrm{R}(\mathrm{tp})]$

Then the total downtime per cycle is as follows [13]:

$\mathrm{D}(\mathrm{tp})=\frac{\mathrm{TpR}(\mathrm{tp})+\mathrm{Tf}\{1-\mathrm{R}(\mathrm{tp})\}}{(\mathrm{tp}+\mathrm{Tp}) \mathrm{R}(\mathrm{tp})+[\mathrm{M}(\mathrm{tp})+\mathrm{Tf}\}[1-\mathrm{R}(\mathrm{tp})\}}$

where:

$\mathrm{D}(\mathrm{tp}):$ total downtime per unit time for preventive replacement

tp : length of preventive cycle (time interval)

Tp : downtime due to preventive action (time needed for component replacement due to preventive action). According to the company

Tf : downtime due to component damage (time required for component replacement due to damage). Obtained from MTTR

$\mathrm{R}(\mathrm{tp})$ : opportunity of the preventive cycle

M (tp) : The average time a damage has occurred, if the replacement is done at tp.

\subsection{Availability}

Availability (availability) can be defined as the probability of a system operating according to its function within a certain time under predetermined operating conditions. Calculation of availability level aims to determine the level of availability or readiness of the machine to operate again when the machine has been repaired.

\subsection{Reliability}

Reliability can be defined as the probability that the system will have performance according to the functions needed in a certain time period. Besides reliability on the component shows how the size of a component to operate properly.

\section{Research Method}

\subsection{Data Collecting}

Primary and secondary data used as input in this study include:

a. Machininig department tool replacement data

b. Time interval data for tool damage on the cylinder liner line

c. Time change tool data on cylinder liner line (downtime) 


\subsection{Analysis}

The analysis phase is as follows:
a. Determine critical tools
b. Calculate TTF (Time to Failure) and TTR (Time to Repaire)
c. Identify TTF and TTR distribution
d. Distribution Match Test (Goodness of Fit Tetsti)
e. Distribution Parameter Calculation
f. Calculate MTTF
g. Calculating MTTR
h. Determine Schedule for Tool Replacement Using the Age Replacement Method with Minimized Downtime Criteria
i. Calculate Downtime Before and After Implementing the Age Replacement Method
j. Calculate the Breakdown Tool
k. Calculating Availability Tool
1. Calculating Reliability Tool

\section{Results and Discussion}

\subsection{Critical Tools}

To calculate the critical tools minitab 16 software is used to process the Pareto chart. The data used to calculate critical tools is data downtime. Critical tools are sought only at the cylinder liner line, because this line has the highest downtime.

Based on the "80-20" pareto principle, the tools that are classified as critical categories on the cylinder liner line are OP6 H1, OP6 H2, OP2 L3, OP1 L1, and OP5 B1 because the cumulative percentage value has exceeded $80 \%$.

\subsection{TTF and TTR}

TTF is the time difference when the first damage is repaired until the next damage. TTF can also be called the time interval between damage. While TTR is the time difference used to make repairs until the machine can operate again or is called downtime. TTF and TTR calculations are performed on critical tools, namely OP6 H1, OP6 H2, OP2 L3, OP1 L1, and OP5 B1. TTF and TTR calculations are used to identify the distribution.

\subsection{Distribution Identification}

Identification is done on the TTF and TTR critical tool data. The following are the results of identifying the distribution of the TTF tool data for critical tools:

Table 1. Identification of TTF Data Distribution on Critical Tools

$\begin{array}{cccc}\text { No. } & \text { Critical Tool } & \boldsymbol{r} \text { value } & \text { Distribution } \\ \text { 1. } & \text { OP1 L1 } & 0.9959 & \text { Lognormal } \\ \text { 2. } & \text { OP2 L3 } & 0.9922 & \text { Lognormal } \\ \text { 3. } & \text { OP5 B1 } & 0.9971 & \text { Lognormal } \\ \text { 4. } & \text { OP6 H1 } & 0.9269 & \text { Eksponensial } \\ \text { 5. } & \text { OP6 H2 } & 0.9971 & \text { Lognormal }\end{array}$

The following are the results of identifying the distribution on the TTR for critical tools:

Table 2. Identification of TTR Data Distribution in Critical Tools

$\begin{array}{cccc}\text { No. } & \text { Critical Tool } & \boldsymbol{r} \text { value } & \text { Distribution } \\ \text { 1. } & \text { OP1 L1 } & 0.9975 & \text { Lognormal } \\ \text { 2. } & \text { OP2 L3 } & 0.9987 & \text { Lognormal } \\ \text { 3. } & \text { OP5 B1 } & 0.9967 & \text { Normal } \\ \text { 4. } & \text { OP6 H1 } & 0.9977 & \text { Normal } \\ \text { 5. } & \text { OP6 H2 } & 0.9929 & \text { Lognormal } \\ & & & \\ & & & \end{array}$




\subsection{Goodness of Fit Test}

Because all TTF tools only lognormal and exponential distributions, for the distribution match test there are only two tests used, namely the Kolmogorov-Smirnov test for the lognormal distribution test and the Bartetet's test for the exponential distribution test. From all test matches the distribution of all TTF data on critical tools results in an acceptable HO decision, so that the distribution truly represents the TTF data or the damage data that occurred. Following is a recapitulation of the distribution match test for TTF data on critical tools.

Table 3. Test Match TTF Data Distribution on Critical Tool

$\begin{array}{llll}\text { No. } & \text { Critical Tool } & \text { Uji Goodness of Fit } & \text { Hypothesis } \\ \text { 1. } & \text { OP1 L1 } & \text { Uji Kolmogorov-Smirnov } & \mathrm{H}_{0} \text { Accepted } \\ \text { 2. } & \text { OP2 L3 } & \text { Uji Kolmogorov-Smirnov } & \mathrm{H}_{0} \text { Accepted } \\ \text { 3. } & \text { OP5 B1 } & \text { Uji Kolmogorov-Smirnov } & \mathrm{H}_{0} \text { Accepted } \\ \text { 4. } & \text { OP6 H1 } & \text { Uji Bartllet's } & \mathrm{H}_{0} \text { Accepted } \\ \text { 5. } & \text { OP6 H2 } & \text { Uji Kolmogorov-Smirnov } & \mathrm{H}_{0} \text { Accepted }\end{array}$

While all TTR tools are only lognormal and normal distribution, for the distribution match test there is only one test used, the Kolmogorov-Smirnov test for the lognormal distribution test. From all test matches the distribution of all TTR data on critical tools results in an acceptable $\mathrm{H} 0$ decision, so that the distribution truly represents the TTR data or data downtime that occurs. The following is a summary of the distribution match test for TTR data on critical tools

Table 4. Goodness of Fit of TTR

$\begin{array}{ll}\text { No. } & \text { Critical Tool } \\ \text { 1. } & \text { OP1 L1 } \\ \text { 2. } & \text { OP2 L3 } \\ \text { 3. } & \text { OP5 B1 } \\ \text { 4. } & \text { OP6 H1 } \\ \text { 5. } & \text { OP6 H2 }\end{array}$

Uji Goodness of Fit
Uji Kolmogorov-Smirnov
Uji Kolmogorov-Smirnov
Uji Kolmogorov-Smirnov
Uji Kolmogorov-Smirnov
Uji Kolmogorov-Smirnov

Uji Goodness of Fit Uji Kolmogorov-Smirnov

Uji Kolmogorov-Smirnov

Uji Kolmogorov-Smirnov

Uji Kolmogorov-Smirnov

\subsection{Parameter Distribution}

After the distribution of each TTF (Time to Failure) and TTR (Time to Repaire) data is identified, the next step is to look for the parameters of each distribution to calculate the values of MTTF and MTTR.

The following parameter values for the critical TTF tool data shown in Table 5.

Table 5. Parameter Distribution of TTF

$\begin{array}{llll}\text { No. } & \text { Critical Tool } & \text { Parameter } & \text { Value } \\ \text { 1. } & \text { OP1 L1 } & \mathrm{S} & 0,505 \\ & & \mathrm{t}_{\text {med }} & 386,62 \\ \text { 2. } & \text { OP2 L3 } & \mathrm{S} & 0,546 \\ & & \mathrm{t}_{\text {med }} & 370,835 \\ \text { 3. } & \text { OP5 B1 } & \mathrm{S} & 0,707 \\ \text { 4. } & \text { OP6 H1 } & \mathrm{t}_{\text {med }} & 525,139 \\ \text { 5. } & \text { OP6 H2 } & \mathrm{S} & 0,00249 \\ & & \mathrm{t}_{\text {med }} & 0,745 \\ & & & 350,842\end{array}$

The following parameter values for the critical TTR tool data shown in Table 6 . 
Tabel 6. Parameter Distribution of TTR

$\begin{array}{llll}\text { No. } & \text { Critical Tool } & \text { Parameter } & \text { Value } \\ \text { 1. } & \text { OP1 L1 } & \mathrm{S} & 0,314 \\ & & \mathrm{t}_{\mathrm{med}} & 4,326 \\ \text { 2. } & \text { OP2 L3 } & \mathrm{S} & 0,303 \\ & & \mathrm{t}_{\mathrm{med}} & 5,645 \\ \text { 3. } & \text { OP5 B1 } & \sigma & 1,126 \\ & & \mu & 4,652 \\ \text { 4. } & \text { OP6 H1 } & \sigma & 0,885 \\ & & \mu & 7,291 \\ \text { 5. } & \text { OP6 H2 } & \mathrm{S} & 0,171 \\ & & \mathrm{t}_{\mathrm{med}} & 7,188\end{array}$

\subsection{Mean Time to Failure}

MTTF (Mean Time to Failure) shows the average time the damage occurred (the average time the tool has finished being replaced until the tool breaks again). MTTF calculations are performed using predetermined parameters. The following are MTTF values from critical tools:

Table 7. Value for MTTF

$\begin{array}{ccc}\text { No. } & \text { Critical Tool } & \text { MTTF } \\ \text { 1. } & \text { OP1 L1 } & 439.425 \\ \text { 2. } & \text { OP2 L3 } & 430.504 \\ \text { 3. } & \text { OP5 B1 } & 674.589 \\ \text { 4. } & \text { OP6 H1 } & 400.993 \\ \text { 5. } & \text { OP6 H2 } & 463.149\end{array}$

\subsection{Mean Time to Repaire}

MTTR (Mean Time to Repaire) shows the average time needed to make repairs. MTTR calculations are carried out using predetermined parameters.

Table 8. Value for MTTR

$\begin{array}{rrr}\text { No. } & \text { Critical Tool } & \text { MTTR } \\ \text { 1. } & \text { OP1 L1 } & 4.545 \\ 2 . & \text { OP2 L3 } & 5.912 \\ \text { 3. } & \text { OP5 B1 } & 4.652 \\ \text { 4. } & \text { OP6 H1 } & 7.291 \\ 5 . & \text { OP6 H2 } & 7.295\end{array}$

\subsection{Tool Change Schedule Using the Age Replacement Method with Minimized Downtime Criteria}

The next step is to calculate the tool replacement schedule using the Age Replacement method to reduce downtime. Tool change time intervals are calculated using parameter values, MTTF (Mean Time to Failure), and MTTR (Mean Time to Repaire) of the distributions that have been tested for compatibility. Calculation of time intervals using trial and error with time (tp) for trial and error must include time from MTTF [2]. The following is 
an example of calculating the OP1 L1 tool replacement schedule using the age replacement method with downtime minimization criteria:

$>$ TTF (Time To Failure) and TTR (Time To Repaire) Distribution

The OP1 L1 TTF tool distribution is a lognormal distribution and the OP1 L1 TTR tool distribution is a lognormal distribution.

$>$ Selected distribution parameter values

The lognormal distribution parameter values for the OP1 L1 TTF tool are $\mathrm{s}=0.505$ and tmed $=$ 386.62. While the lognormal distribution parameter values on the OP1 L1 TTF tool are s $=0.314$ and tmed $=4.326$.

$>$ MTTF values, and MTTR distribution selected The value of the MT1 tool OP1 L1 is 439,425 and the value of the MT1 tool OP1 L1 is 4,545.

$>$ Determine the value (tp) length of the preventive cycle (time interval)

The value (tp) for the initial calculation is equal to the MTTF value of 439,425 minutes.

$>$ Determine the value (Tp) of downtime due to preventive measures

The Tp value for the OP1 L1 tool is 3 minutes.

$>$ Determine the value (Tf) of downtime due to component damage

The value (Tf) for the OP1 L1 tool is 4,545 minutes or equal to the MTTR value.

$>$ Calculates F (tp) the cumulative damage function (TTF), the following is the cumulative damage function, if the current replacement is 439,425 (MTTF).

$$
\begin{aligned}
& \mathrm{F}(\mathrm{t})=\phi\left(\frac{1}{\mathrm{l}} \ln \frac{\mathrm{t}}{\mathrm{tm} e \mathrm{~d}}\right) \\
& \mathrm{F}(\mathrm{t})=\phi\left(-\ln \frac{\mathrm{t}}{\mathrm{tmed}}\right) \\
& F(439,425)=\phi\left(\frac{1}{0,505} \ln \frac{439,425}{386,62}\right) \\
& \mathrm{F}(439,425)=0,599 \\
& \mathrm{R}(\mathrm{t})=1-\phi\left(-\frac{1}{\mathrm{~g}} \ln \frac{\mathrm{t}}{\mathrm{tm} e \mathrm{~d}}\right) \\
& \mathrm{R}(439,425)=1-\phi\left(\frac{1}{0,505} \ln \frac{43 y, 42 \mathrm{~b}}{386,62}\right) \\
& \mathrm{R}(439,425)=0,4001 \\
& \mathrm{M}\left(\mathrm{t}_{\mathrm{p}}\right)=\frac{\mathrm{MTTF}}{\mathrm{F}\left(\mathrm{t}_{\mathrm{p}}\right)} \\
& M(439,425)=\frac{439,425}{0,599} \\
& M(439,425)=732,540
\end{aligned}
$$

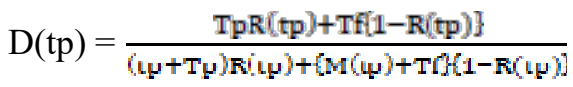

$$
\begin{aligned}
& \mathrm{D}(\mathrm{tp})=\frac{\mathrm{TpR}(\mathrm{tp})+\mathrm{Tf}(1-\mathrm{R}(\mathrm{tp})]}{(\mathrm{tp}+\mathrm{Tp}) \mathrm{R}(\mathrm{tp})+(\mathrm{M}(\mathrm{tp})+\mathrm{Tf} / \mathrm{I}-\mathrm{R}(\mathrm{tp})]} \\
& \mathrm{D}(439,4)=\frac{[3 \times 0,4001)+(4,545 \times[1-0,4001\})}{((439,4+3) \times 0,4001)+((732,540+4,545] \times[1-0,4001\})} \\
& \mathrm{D}(439,4)=\frac{1,2003+2,726}{177,004+(737,085 \times 0,599)}
\end{aligned}
$$




$$
\begin{aligned}
& \mathrm{D}(439,4)=\frac{3,926}{618,617} \\
& \mathrm{D}(439,4)=0,006343
\end{aligned}
$$

So the value of downtime during the replacement interval 439.4 (MTTF) is 0.006343 .

$>$ Age Calculation of age replacement by trial and error using the change time interval (tp) 50 - 1000 minutes.

Table 9. Age Replacement for OP1 L1

\begin{tabular}{|c|l|l|l|l|}
\hline $\begin{array}{c}\text { tp } \\
\text { (Minutes) }\end{array}$ & \multicolumn{1}{|c|}{ R(tp) } & \multicolumn{1}{|c|}{ F(tp) } & \multicolumn{1}{|c|}{$\mathbf{M ( t p )}$} & \multicolumn{1}{|c|}{$\mathbf{D ( t p )}$} \\
\hline 50 & 0.99997355 & 0.000026 & 16613279 & 0.0060924 \\
\hline 100 & 0.996236108 & 0.003764 & 116747.51 & 0.0055452 \\
\hline 150 & 0.96934254 & 0.030657 & 14333.38 & 0.0051837 \\
\hline $\mathbf{2 0 0}$ & $\mathbf{0 . 9 0 3 6 5 5 4 9 9}$ & $\mathbf{0 . 0 9 6 3 4 5}$ & $\mathbf{4 5 6 0 . 9 7 6 7}$ & $\mathbf{0 . 0 0 5 0 5 2}$ \\
\hline 250 & 0.805563259 & 0.194437 & 2259.9897 & 0.0051242 \\
\hline 300 & 0.691932714 & 0.308067 & 1426.393 & 0.005344 \\
\hline 350 & 0.577962929 & 0.422037 & 1041.2001 & 0.0056594 \\
\hline 400 & 0.473204855 & 0.526795 & 834.14782 & 0.0060303 \\
\hline 439.4 & 0.40013592 & 0.599864 & 732.54098 & 0.0063426 \\
\hline 450 & 0.382091185 & 0.617909 & 711.14866 & 0.0064278 \\
\hline 500 & 0.305649748 & 0.694350 & 632.85787 & 0.0068307 \\
\hline 550 & 0.243031923 & 0.756968 & 580.50668 & 0.0072239 \\
\hline 600 & 0.192547927 & 0.807452 & 544.2119 & 0.0075968 \\
\hline 650 & 0.152272524 & 0.847727 & 518.35647 & 0.0079423 \\
\hline 700 & 0.120358484 & 0.879642 & 499.55012 & 0.0082565 \\
\hline 750 & 0.095174277 & 0.904826 & 485.64603 & 0.0085377 \\
\hline 800 & 0.075345139 & 0.924655 & 475.2314 & 0.008786 \\
\hline 850 & 0.059745776 & 0.940254 & 467.34704 & 0.0090029 \\
\hline 900 & 0.047472082 & 0.952528 & 461.32509 & 0.0091907 \\
\hline 950 & 0.037806431 & 0.962194 & 456.69088 & 0.0093519 \\
\hline 1000 & 0.030183682 & 0.969816 & 453.10129 & 0.0094896 \\
\hline The Least D(tp) & & & 0.005052 \\
\hline & & & & \\
\hline
\end{tabular}

Determine the OP1 L1 (tp) tool change interval with the lowest D (tp).

Based on the age replacement calculation table above. the OP1 L1 tool change interval when the value (tp) with the lowest downtime is 200 minutes. So the OP1 L1 tool is replaced every 200 minutes or 3.33 hours.

$>$ Following is the recapitulation of scheduling using age replacement with the criteria for minimizing downtime on critical tools:

Table 10. Age Replacement

$\begin{array}{lllr}\text { No. } & \text { Critical Tool } & \begin{array}{l}\text { The least } \\ \text { D(tp) }\end{array} & \begin{array}{r}\text { (tp) to the least } \\ \text { (Minute) }\end{array} \\ \text { 1. } & \text { OP1 L1 } & 0.005052 & 200 \\ \text { 2. } & \text { OP2 L3 } & 0.006974 & 200 \\ \text { 3. } & \text { OP5 B1 } & 0.003639 & 250 \\ \text { 4. } & \text { OP6 H1 } & 0.011167 & 200 \\ \text { 5. } & \text { OP6 H2 } & 0.010057 & 250\end{array}$




\section{Discussion}

\subsection{Downtime Before and after Age Replacement method}

In the calculation of downtime. The calculation is done before and after applying the Age Replacement method. In the calculation of downtime before applying the Age Replacement method. The calculation is done using the value of $\mathrm{D}(\mathrm{tp})$ when the average downtime value or when the value of MTTF (Mean Time to Fepaire) is done. Whereas to determine the calculation of downtime after the application of the Age Replacement method is to use the value D (tp) when the downtime value is at a minimum.

The following is an example of calculating downtime before and after using the age replacement method with the criteria for minimizing downtime on the tool OP1 L1.

$>$ Determine the duration

Tool damage data taken for the study is for 3 months (April - June 2018). During the data collection period there were 61 working days with 24-hour work hours per day divided into 3 work shifts.

Duration $=61$ Days $\times 24$ Hours $\times 60$ Minutes $=87840$ minutes.

$>$ Calculation of OP1 L1 Downtime Tool Before Applying Age Replacement

The $\mathrm{D}$ value (tp) when MTTF is 0.00634

Downtime $=\mathrm{D}(\mathrm{tp}) \times$ Duration

Downtime $=0.00634 \times 87840$

Downtime $=557.136$ Minutes

$>$ OP1 L1 Downtime Tool Calculation After Age Replacement Application

The smallest value of $\mathrm{D}(\mathrm{tp})$ is 0.005052

Downtime $=\mathrm{D}(\mathrm{tp}) \times$ Duration

Downtime $=0.005052 \times 87840$

Downtime $=443.765$ Minutes

Total downtime before the application of age replacement is 3612.636 minutes. While the total downtime after applying age replacement is 3240.45 minutes. Then there was a decrease in total downtime by 372.177 minutes or $10.3 \%$

\subsection{Breakdown Tool}

To determine the breakdown can be determined before and after the application of age replacement. To determine the breakdown before the application of age replacement can be used data breakdown tool from the company. Whereas to be able to determine the breakdown after the application of the age replacement method the tp value (replacement interval) is used when D (tp) has the lowest total downtime.

The following is a recapitulation of downtime tool calculations on critical tools before and after the application of the age replacement method. It shows in Table 11.

Table 11. Tool: Breakdown

\begin{tabular}{|c|c|c|c|}
\hline No. & Critical Tool & $\begin{array}{c}\text { Breakdown Per day before } \\
\text { Age Replacement }\end{array}$ & $\begin{array}{c}\text { Breakdown Per day after } \\
\text { Age Replacement }\end{array}$ \\
\hline 1. & OP1 L1 & 3 & 7 \\
\hline 2. & OP2 L3 & 3 & 7 \\
\hline 3. & OP5 B1 & 2 & 6 \\
\hline 4. & OP6 H1 & 5 & 7 \\
\hline 5. & OP6 H2 & 3 & 6 \\
\hline
\end{tabular}

\subsection{Availability Tool}

Availability shows the ability of the component to function after the maintenance action is taken. Thus the greater the availability value indicates the higher the ability of the component, or the availability 
value closer to number 1 . The better the condition of the component can operate according to its function. To be able to calculate the availability value. Use the D (tp) value at least the lowest or lowest.

The following is a recapitulation of the calculation of the availability of tools after the application of the age replacement method. It shows in Table 12.

Table 12. Availability

\begin{tabular}{|c|c|c|}
\hline No. & Critical Tool & Availability \\
\hline 1. & OP1 L1 & 0.9949 \\
\hline 2. & OP2 L3 & 0.9930 \\
\hline 3. & OP5 B1 & 0.9963 \\
\hline 4. & OP6 H1 & 0.9888 \\
\hline 5. & OP6 H2 & 0.9899 \\
\hline
\end{tabular}

\subsection{Reliability Tools}

To determine reliability can be determined before the application of the age replacement method and after the application of the age replacement method. To be able to determine the reliability value before applying the age replacement method is to use the tp value (replacement time interval) during MTTF (Mean Time to Failure). Meanwhile, to determine the value of reliability after the application of the age replacement method by using the value of tp (replacement time interval) at the time of D (tp) the total minimum downtime for preventive activities. The reliability formula used depends on the selected distribution that has been tested for goodness of fit.

The following is a recapitulation of reliability calculations on critical tools before and after the application of the age replacement method. It shows in Table 13.

Tabel 13. Reliability Recapitulation

\begin{tabular}{|c|c|c|c|c|}
\hline No. & Critical Tool & $\begin{array}{c}\text { Reliability before Age } \\
\text { Replacement }\end{array}$ & $\begin{array}{c}\text { Reliability after Age } \\
\text { Replacement }\end{array}$ & $\begin{array}{c}\text { Increase of } \\
\text { Reliability }\end{array}$ \\
\hline 1. & OP1 L1 & 0.4001 & 0.9036 & 0.5035 \\
\hline 2. & OP2 L3 & 0.3923 & 0.8708 & 0.4784 \\
\hline 3. & OP5 B1 & 0.3617 & 0.8528 & 0.4911 \\
\hline 4. & OP6 H1 & 0.3678 & 0.6072 & 0.6072 \\
\hline 5. & OP6 H2 & 0.3547 & 0.6753 & 0.3206 \\
\hline
\end{tabular}

\section{Conclusion}

To determine the tool change interval by reducing downtime on the cylinder liner line machining department is using the age replacement method with the criteria for minimizing downtime, availability and reliability. Because after calculating using the age replacement method. It can be seen the tool change schedule or tool replacement interval in the cylinder liner line.

- The change interval on the OP1 L1 tool is done after operating 200 minutes.

- The replacement interval on the OP2 L3 tool is done after operating 200 minutes.

- The replacement interval on the OP5 B1 tool is done after operating 250 minutes.

- The replacement interval on the OP6 H1 tool is done after operating 200 minutes

- The interval replacement of the OP6 H2 tool is carried out after 250 minutes of operation.

Determination of tool change intervals based on the smallest total downtime D (tp) can reduce the total downtime in the cylinder liner line which before the application of the age replacement method is 3612.636 minutes. Whereas after applying the age relacement method it drops to 3240.45 minutes.

Then there was a decrease in total downtime by 372.177 minutes or down by $10.3 \%$. After calculating using the availability method on a critical tool. The availability value of the tool approaches number 1 . Which means the better the tool's state is to operate according to its function. And finally the calculation is done using the reliability method which obtained the value of reliability after the application of age replacement is greater than before the application of age replacement. 
Where the higher the value of the reliability of a tool. The less likely the damage will occur to these components.

\section{References}

[1] T. Taufik, and S. Septyani, "Penentuan Interval Waktu Perawatan Komponen Kritis pada Mesin Turbin di PT PLN (Persero) Sektor Pembangkit Ombilin,” Jurnal Optimasi Sistem Industri, vol. 14, no. 2, pp. 238-258, 2016.

[2] S. D. Mutiara, A. Rahman, and I. Hamdala, "Perencanaan Preventive Maintenance Komponen Cane Cutter I dengan Pendekatan Age Replacement (Studi Kasus di Pg Kebon Agung Malang). Jurnal Rekayasa dan Manajemen Sistem Industri, vol. 2, no. 2, pp. 396-405, 2014.

[3] E. Santoso, and E. J. Chairul, Minimasi Downtime Tool Punch Mesin Heading Pada Preventive Maintenance dengan Metode Age Replacement. Jakarta: Universitas Bina Nusantara, 2007.

[4] F. Afrinaldi, "Penentuan Optimal Preventive Replacement Age Untuk Meminimasi Downtime Blade dan Sambungan as Cake Breaker Conveyor (Studi Kasus PT. X)," Reka Integra, vol. 2, no. 2, 2014.

[5] M. Djunaidi, and M. F. Sufa, Usulan Interval Perawatan Komponen Kritis pada Mesin Pencetak Botol (Mould Gear) Berdasarkan Kriteria Minimasi Downtime. Jakarta: Universitas Bina Nusantara, 2007

[6] W. A. P. Dania, I. Purwaningsih, and F. A. Aristiono, "Application of Optimal Preventive Replacement Age Model to Determine Replacement Schedule For Dumping Grate Component on Boiler Machine (Case Study at Rejo Agung Baru Sugar Factory Madiun)," Jurnal Teknologi Pertanian, vol. 12, no. 1, 2012.

[7] J. Purnama, Y. A. Putra, and M. Kalamollah, "Metode Age Replacement Digunakan Untuk Menentukan Interval Waktu Perawatan Mesin Pada Armada Bus," Reka Integra, vol. 3, no. 1, pp. 115-126, 2015.

[8] J. W. Krisnadi, K. Soemadi, and F. H. Mustofa., "Optimisasi Waktu Penggantian Komponen Pada Lokomotif De Cc 201 Seri 99 Menggunakan Metoda Age Replacement di PT. Kereta Api Indonesia," Reka Integra, vol. 1, no. 4, 2013.

[9] B. S. Abbas, E. Steven, H. Christian, and T. Sumanto "Penjadwalan Preventive Maintenance Mesin B. Flute Pada PT. AMW," Inasea, vol. 10, no. 2, pp. 97-104, 2009.

[10] D. V. Suherman, K. Leksananto, and F. H. Mustofa, "Interval Waktu Penggantian Pencegahan Optimal Komponen Sistem Printing Unit U41 Menggunakan Metode Age Replacement di PT. Pikiran Rakyat," Reka Integra, vol. 3, no. 1, 2015.

[11] F. Mangngi, "Evaluasi Kondisi Mesin Bubut Harizon T300 Menurut Metode Schlesinger Sebagai Acuan Dalam Melakukan Tindakan Perawatan," Jurnal Mesin Teknologi, vol. 12, no. 2, pp. 87-99, 2018.

[12] C. E. Ebeling, an Introduction to Reliability and Maintainability Engineering. Tata McGrawHill Education, 2014.

[13] A. H. Tsang, A. K. Jardine, and H. Kolodny "Measuring maintenance performance: a holistic approach," International Journal of Operations \& Production Management, vol. 19, no. 7, pp. 691-715, 1999. 